\title{
Rapid Near Infrared Reflectance Analysis (NIRA) of Mainstream Smoke Collected on Cambridge Filter Pads
}

by

Di Luzio C,

Amministrazione Autonoma dei Monopoli di Stato,

Manifattura Tabacchi, Bologna, Italy

Morzilli S.,

Amministrazione Autonoma dei Monopoli di Stato, Roma, Italy

and

Cardinale E.,

PerCon Research and Development Techniques, Roma, Italy

\section{SUMMARY}

Near infrared (NIR) reflectance spectroscopy has been used for rapidly and reproducibly measuring the NIR spectra of mainstream smoke collected on Cambridge filter pads and quantifying the chemical composition from the spectral data.

This technique has four main advantages: speed, simplicity of sample preparation, multiple analytes from one scan of a sample, and non-destruction of the sample.

The study has been conducted in our research laboratory to define the possible use of NIRA (Near Infrared Reflectance Analysis) as an instrumental screening tool for analysing mainstream smoke collected on Cambridge Filter pads. A major advantage of this method is that it eliminates the use of dangerous chemicals such as cyanogen bromide or chloride involved with some standard assays.

Using specific wavelengths, we are able to determine with acceptable accuracy water, nicotine and tar. Corre-

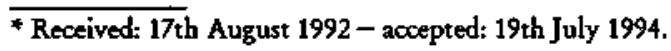

lation coefficients of NIRA results compared with those obtained by standard methods are better than 0.9 for all analyses.

NIRA cannot replace ISO standard methods, flow analysis or chromatography, but as a reliable screening analysis, it could reduce the routine work load by $80 \%$. These savings could be achieved by prescreening samples with NIRA and analysing only suspect samples by distillation or continuous flow analysis.

\section{ZUSAMMENFASSUNG}

Nah-Infrarot-Reflektions (NIR) Spektroskopie wurde zur schnellen und reproduzierbaren Messung von NIR Spektren von Rauchkondensat auf Cambridge-Filtern verwendet und die chemische Zusammensetzung per Computer aus den Spektraldaten abgelesen.

Dieses Verfahren hat vier hauptsächliche Vorteile: Schnelligkeit, Einfachheit der Probenvorlage, Mehrfachbestimmungen aus dem einmaligen Messen einer Probe, und die Probe wird weder chemisch noch physikalisch 
zerstört.

Diese Studie wurde in unserem Forschungslabor durchgeführt, um den möglichen Einsatz der NIRA (NahInfrarot-Reflektions-Analyse) als Instrumentarium für Auslesetests von berauchten Cambridge-Filterscheiben zu definieren. Der Hauptgrund für diese Studie ist, daß herkömmliche Routinemethoden den Einsatz gefährlicher Chemikalien, wie z.B. Brom oder Chlorzyanide, erfordern.

Man erreicht die Bestimmung von Feuchtigkeit, Nikotin und Kondensat mit akzeptabler Genauigkeit bei Verwendung spezifischer Wellenlängen. Die Korrelationen zu herkömmlichen Standardmethoden für alle erwähnten Parameter sind besser als 0.9.

Nah-Infrarot-Analysen können ISO Standard-Methoden, Flow-Analysen oder Chromatografie nicht ersetzen, aber als verläßliche Ausleseanalyse (Screening) könnten sie die Routinearbeit um $80 \%$ reduzieren, weil dann nur die von NIRA ausgelesenen, dubiosen Proben der Destillation oder Continuous Flow Analysen unterzogen werden müssen.

\section{RESUME}

La spectroscopie par réflexion dans le proche infrarouge (NIR) a été utilisé pour mesurer rapidement et reproductiblement les spectres d'échantillons collectés sur filtres Cambridge et pour quantifier la composition chimique par voie d'analyse spectrale.

Cette technique a quatre avantages principaux: vitesse, simplicité de la préparation de l'échantillon, analyse multiparametrique sur la base d'un seul échantillon et non-destruction de l'échantillon.

L'étude a été réalisée dans notre laboratoire de recherche pour définir l'usage possible de la technique NIRA (analyse par réflexion dans le proche infrarouge) comme instrument de sélection. L'avantage principal de cette méthode est qu'elle évite l'usage de produits chimiques dangereux tels que le bromure ou le chlorure de cyanogène utilisés dans les analyses traditionnelles.

Il est possible de mesurer avec une précision acceptable l'humidité, la nicotine et le 'goudron' grâce aux longueurs d'ondes spécifiques. Les coéfficients de corrélation obtenus par NIRA comparés aux valeurs obtenus par les méthodes standard sont meilleurs que 0.9 pour tous les paramètres mentionnés.

La méthode NIRA ne remplace pas les méthodes standard ISO, les analyses à flux continu ou chromatographique, mais elle peut réduire le travail de routine de $80 \%$. Ceci peut être atteint par une pré sélection d'échantillons au moyen de NIRA qui permet de séparer les échantillons suspects pour lesquels une analyse additionnelle s'ajoute.

\section{INT'RODUCTION}

Near infrared is a very narrow region between the visible light and the analytical infrared zone. This region (1000 $\mathrm{nm}$ to $2600 \mathrm{~nm}$ ) corresponds to frequencies of stretching and bending overtones of many chemical bonds, therefore absorbances are not very high, but at the same time, peaks are relatively thin and interferences are reduced.

Near Infrared Analysis, or Near Infrared Reflectance Analysis (NIRA), is a rapid (less than 30 seconds), nondestructive analytical technique involving a spectrometer and computerized data processing. The task of the computer is to interpret the optical data using a variety of multivariate mathematical techniques so as to produce a measurement of some constituent(s) (or component) found within the sample chemistry.

NIRA technology involves multidisciplinary approaches of the analytical chemist, statistician, and computer programmer. Knowledge of optics and electronics is also essential in the advanced use of this technology.

Over the years, research has demonstrated the feasibility of using Near Infrared Reflectance Spectroscopy (NIRS) for measuring many chemical components in materials coming from agriculture and the agricultural industry (113), but also for measuring sugar, nicotine, nitrogen, and others on tobacco samples $(3,1422)$. The technology can be used to essay chemical constituents in samples which are chemically complex. The general procedure consists in developing a calibration equation by means of a selected calibrating set of samples. These samples have to be analyzed with reference methods and numerical results are correlated by computer with optical data to achieve out the best calibration.

Practically, the reflectance data $(\log 1 / R)$, are collected in a raw data matrix of $S$ rows and $N$ columns, where $S$ is the number of the samples examined at $N$ fixed wavelengths. The spectroscopic information is used for calibration by linear regression modelling after removing redundant data. The concentration of a chemical component can finally be expressed as:

\section{Percent constituent =}

$$
C_{0}+C_{1} \log \left(1 / R_{\mathrm{v}}\right)+C_{2} \log \left(1 / R_{2}\right)+\ldots+C_{n} \log \left(1 / R_{n}\right)
$$

$C_{0} \quad-\quad$ intercept from regression (constant term);

$C_{n} \quad$ - coefficient of the $\mathrm{n}(\mathrm{th})$ term (experimentally determined);

$R_{n} \quad-\quad$ measured diffuse reflectance at the $n(t h)$ wavelength.

This chemometric approach allows to get considerable chemical information from samples of varying complexity. 
NIRS has been used for rapidly and reproducibly measuring the NIR spectra of smoke collected on a Cambridge filter and computing the chemical composition from the spectral data. It has four main advantages: speed, simplicity of sample presentation, multiplicity of analysis from one scan of a sample and nondestruction of the sample.

In addition to the above, the main reason to develop this method was the use of toxic reagents such as cyanogen bromide or cyanogen chloride in some tobacco smoke analysis.

This paper discusses the basic factors involved in calibration and instrumental changes needed to perform analysis of smoke constituents collected on Cambridge filter with precision sufficient to justify its use.

\section{Glossary and terminology}

WTPM (Wet Total Particulate Matter) is the mainstream smoke deposited on a Cambridge filter which comes from combustion products generated when a cigarette is 'smoked' by a machine. It is generally calculated by a difference in weight and expressed as milligrams per cigarette (mg/cig).
WTPM = weight of a Cambridge filter after smoke collection minus its tare weight.

The WTPM value includes moisture.

DTPM means Dry Total Particulate Matter; it is expressed as milligrams per cigarette (mg/cig).

DTPM - WTPM - water

NFDPM the Nicotine Free Dry Particulate Matter (also tar) is calculated by substracting water and nicotine from WTPM; it is expressed as milligrams per cigarette $(\mathrm{mg} / \mathrm{cig})$.

NFDPM (tar) - WTPM - nicotine - moisture

MOISTURE is needed for calculation of other parameters, it is generally obtained by Karl Fischer titration or by weight difference; it is expressed as milligrams per cigarette (mg/cig).

SEE (Standard Error Estimate): between the laboratory values and the NIRA values determined in the calibration step.

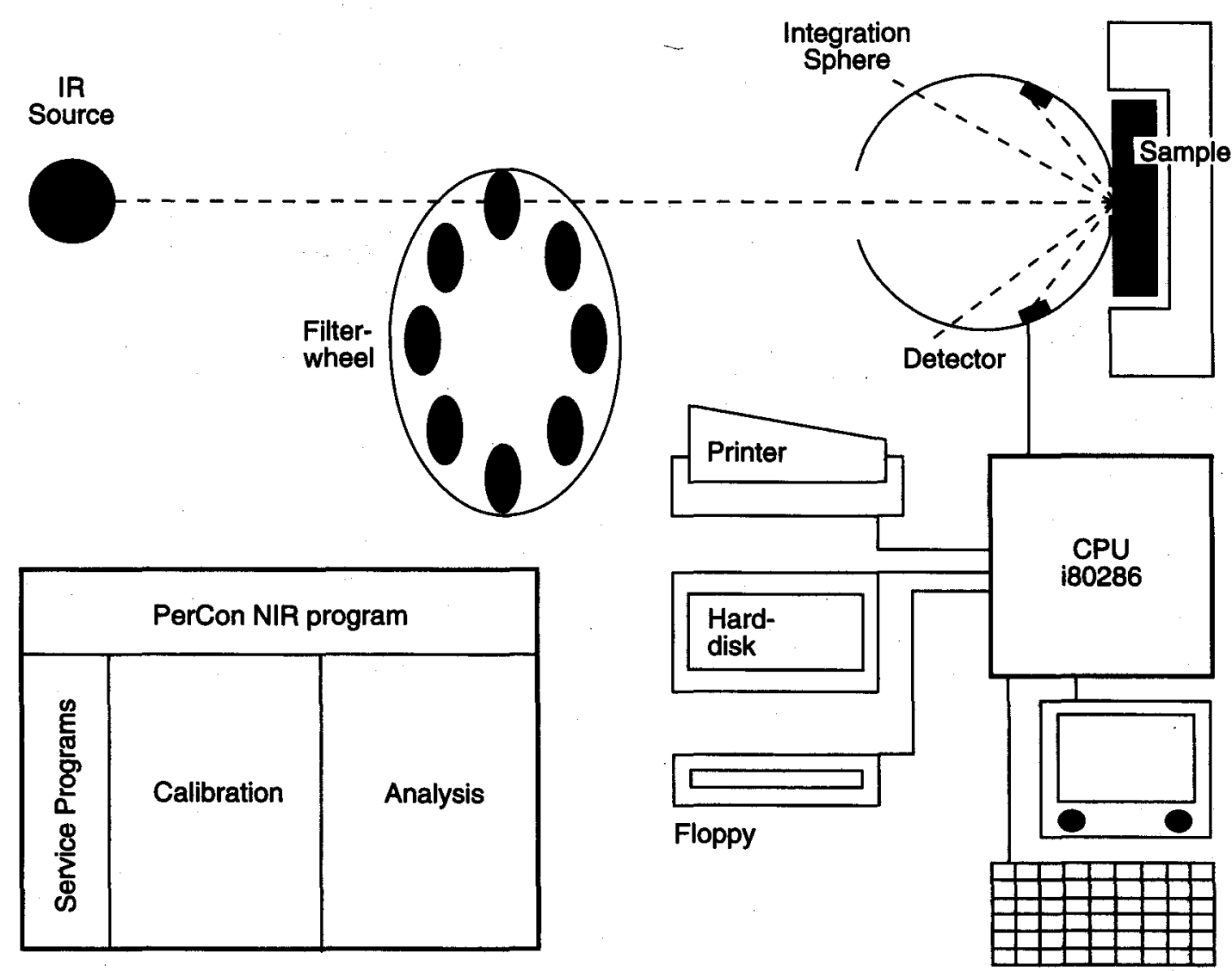

Figure 1.

Schematic representation of the Inframatic 8620 , Its operation and connection with the PC MS-DOS, and operative scheme of the software. 
(Standard Error of Prediction): between the laboratory values and the NIRA values determined in the analyses step.

\section{MATERIALS AND METHODS}

\section{Instruments and samples}

Optical measurements were carried out by means of an INFRAMATIC 8620 manufactured by PERCON, a 20 filter reflectance analyzer connected to a i80286 MSDOS personal computer (see Figure 1).

The standard software supplied by the PerCon was used. This package, a set of compiled programs, is basically divided into two parts: the first one to collect and elaborate the data in order to carry out the calibration curves, the second one to statistically process data obtained in the following analytical steps.

Table 1.

Type of cigarettes included on calibration or tested.
Cigarettes used in this work were produced in different factories located in Italy and abroad. The whole sample set consisted of commercially available products (see Table 1).

In order to obtain a reference sample set incorporating all significant variations such as blend type and nicotine levels, a large number of samples was collected. The intent is to have a population which is representative of samples intended to be measured with the generated calibration curve.

\section{Reference laboratory determinations}

Cigarettes were smoked on a FILTRONA machine, model SM-350. In this procedure, five cigarettes are smoked consecutively under carefully controlled conditions. The mainstream smoke is drawn through a special glass fibre filter (Cambridge filter) which traps the parti-

\begin{tabular}{ll}
\hline Alfa & Alfa F. \\
Bis & Cartier \\
Colombo & Cortina \\
Danhill & Diana \\
Diana Mild & Diana S.M. \\
Esportazione & Esportazione Filtro \\
Futura & Gala \\
Gallant & Galonese \\
Kim & Kim Menthol \\
Kim Super 100 & Lido \\
Lido Extra Mild & Linda \\
Linda Leggera & Lucky S. \\
Lucky ST.L. & Lucky Str. \\
Marboro & Martboro Light \\
Mercedes & Merit \\
Milde Sorte & Milde Sorte 100 \\
MS & MS Blu \\
MS Blu V.E. & MS De Luxe \\
MS De Luxe Extra Lights & MS Extra Lights \\
MS Intemational & MS Light \\
MS Mild & Mundial \\
Muratti & Muratti Ambassador \\
Muratti E.M. & Muratti U.N. \\
N 80 K.S.F. & N.E.L. \\
Nazionali & Nazionali Filtro \\
Now & Nuova \\
Nuova 3 Bis & Philip Morris S.L. \\
PM Multifilter & PM Super 100 \\
R6 Internatlonal & R6 S.L. \\
R6 Ultra & Rothmans \\
Rothmans K.S. & Rothmans Lux 100 \\
Rothmans Super & Slim Line \\
Stop K.S.F. & Super \\
Super Filtro & Vantage \\
Winston & Zenit \\
\hline & \\
& \\
\hline
\end{tabular}


culate phase of the cigarette aerosol. Laboratory determination of mainstream smoke collected on Cambridge filters for selected samples were carried out by reference methods according to ISO procedures no. 3308 and 4387.

Wet total particulate matter (WTPM), was measured by simply weighing the smoke collection filter and holder immediately after the sample smoking and comparing with the weight prior to smoke.

Water was determined by means of Karl Fischer titration, using an automated amperometric titrimeter (Methler mod. DL-18)

Nicotine was determined by distillation according to ISO procedures no. 3400 and, in routine operations, by a continuous flow method, using on-line cyanogen chloride generation (23).

NEDPM (tar) was determined by calculation.

Because the reference method results are the basis for both development of the instrument's calibration and for its evaluation, we decided to estimate the reliability and precision of the Auto Analyzer method against the standard distillation procedure.

The statistical results obtained from 80 different samples are shown below:

\begin{tabular}{lcc}
\hline & Correlation & S.D. \\
\hline AA/Distillation & 0.998 & $0.024 \mathrm{mg}$ \\
NIR/Distillation & 0.995 & $0.037 \mathrm{mg}$ \\
\hline
\end{tabular}

Distillation Reproducibility: S.D. $0.015 \mathrm{mg}$ at $1 \mathrm{mg}$ nicotine level.

Reagents

Only high purity reagents were used: sodium hypochlorite ( $7 \%$ available chlorine), potassium thiocyanate, acetic acid and sodium acetate (buffer solution $\mathrm{pH} 4.5$ ), disodium tetraborate decahydrate (buffer solution $\mathrm{pH} 9$ ), nicotine hydrogen tartrate were supplied by Merk and Carlo Erba. Methanol, the solvent used in the extraction of the Cambridge filter pads, was a reagent specially dried for the preparation of Karl Fischer reagent and for non aqueous titrations, and was supplied by $\mathrm{BDH}$. The Karl Fischer reagents were supplied by Riedel-de Haen.

\section{Sample preparation and presentation}

A preliminary study was needed to find the best operating condition for preparing and handing samples $(24,25)$.

Standard door for powdered samples
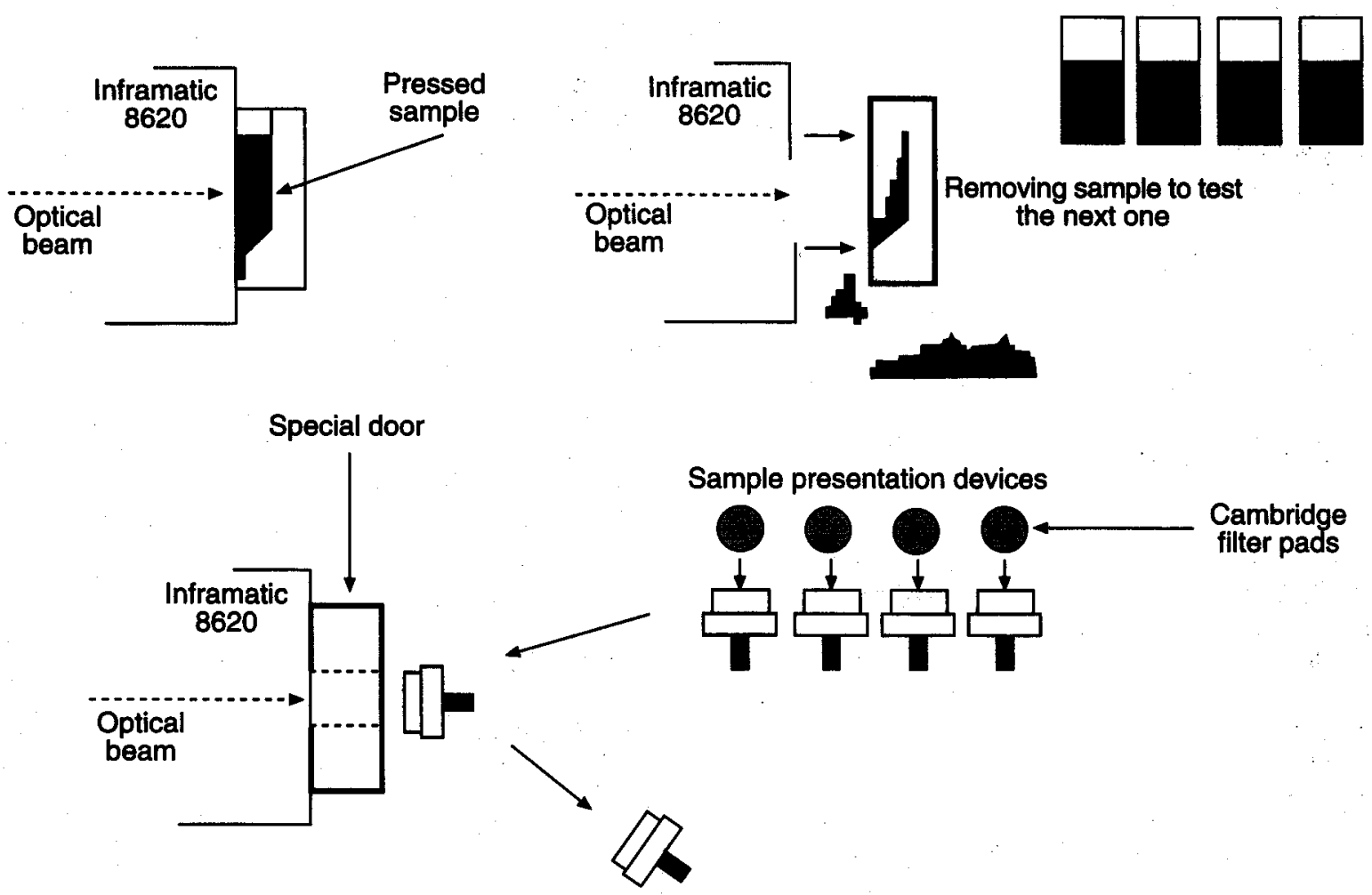

Figure 2.

Standard door of the Inframatic 8620 at measurement time and discharge analysed sample time; below is showed the speclal door (rectangular with a hole in the centre) which keeps the sample preparation devices on. 
At first, a special aluminium presentation device was prepared as shown in Figure 2 to hold the Cambridge filter pad to avoid filter manipulation during the transfer from the smoking machine to the analytical procedure; to avoid moisture variations, the presentation device was provided with a cover. A special door was also constructed to allow direct housing of the presentation device. The filter pad was laid down on the presentation device and this was housed on the special door facing the optical window; the distance window to filter pad was constant (about $3 \mathrm{~mm}$ ).

Samples were obtained at a smoking laboratory maintained at standard condition according to ISO 3402 . The Cambridge filters used were presented to the Inframatic instrument immediately after weighing for WTPM measurement. Filters were removed from the holder without wiping the inside surface of the holder and placed in the aluminium presentation device. $\log 1 / R$ data were obtained at the twenty following wavelengths (in nm): 2345, 2336, 2310, 2270, 2230, 2208, 2190, 2180, $2139,2100,2050,1982,1940,1818,1778,1759,1734$, $1722,1680,1445$. One measurement was performed for each Cambridge filter in order to minimize exposure to ambient humidity.

\section{Instrument modifications}

The configuration of the standard optic of the Inframatic 8620 does not permit reading the whole Cambridge filter surface, however the WTPM produces a $38 \mathrm{~mm}$ diameter spot. So a modification of the optics in the way we have accomplished, allows us to read a surface area with a $38 \mathrm{~mm}$ diameter. Such a modification consisted essentially in removing a projection that obstructed the optical window.

\section{RESULTS AND DISCUSSION}

The choice of the best wavelengths to incorporate in the calibration was carried out with the software.

Comparison among nicotine spectrum (Figure 3) and absorption data obtained from 20 wavelengths (Figure 4) has been of great help.

Regarding the determination of the best calibration curve, the following statistical tests were used:

1) coefficient T-value;

2) F-test for overall equation fitness;

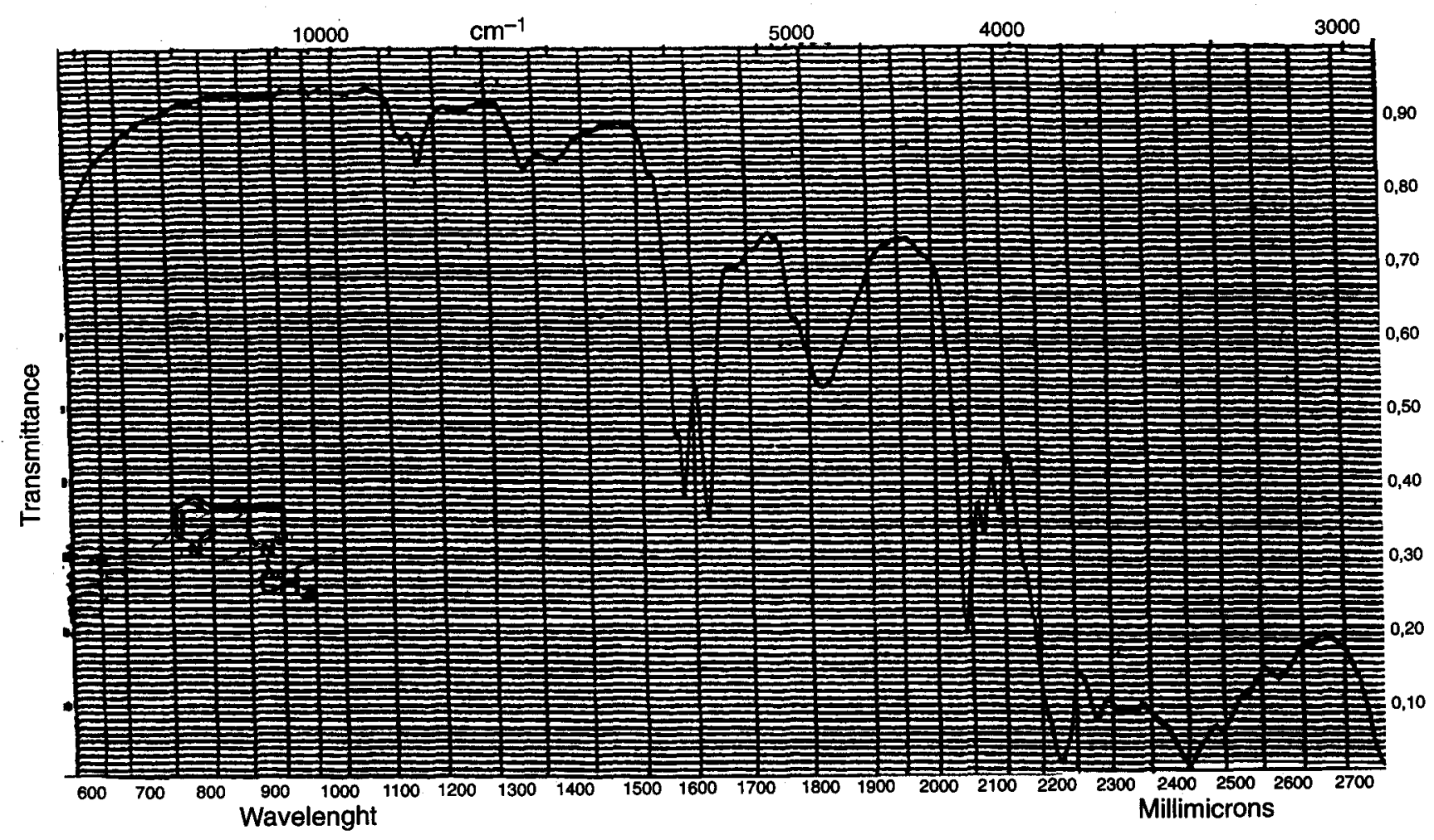

Figure 3.

Nicotine spectrum from literature data. (Slit: $0.28 \mathrm{~mm} / 2.70 \mu$;scan time: 7 min.; cell: $1 \mathrm{~mm}$; conc.: undiluted) 


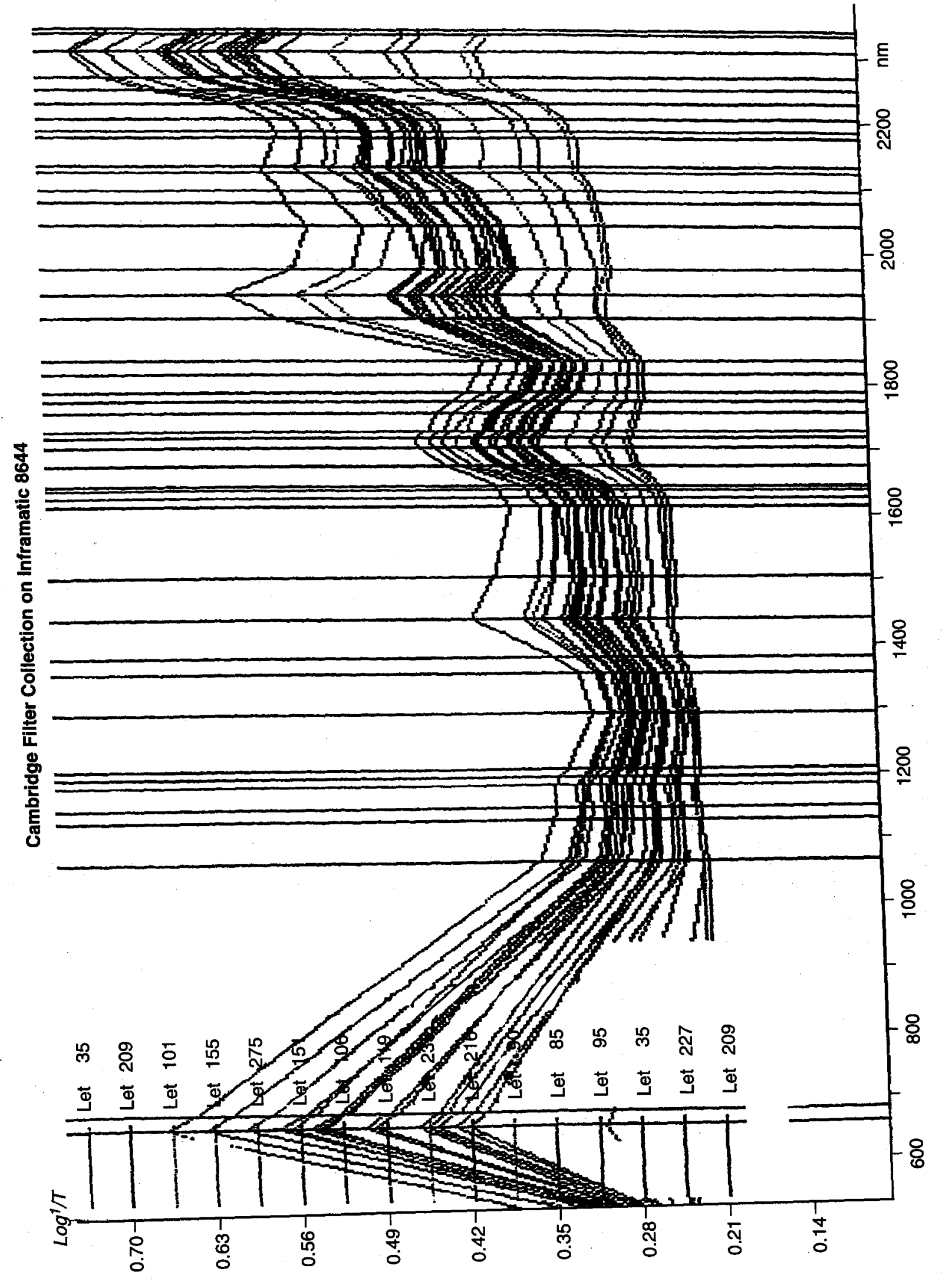

Figure 4.

Absorbance values $(\log 1 / T)$ at the 20 wavelengths of the 8620 for different samples. 
Nicotine Calibration

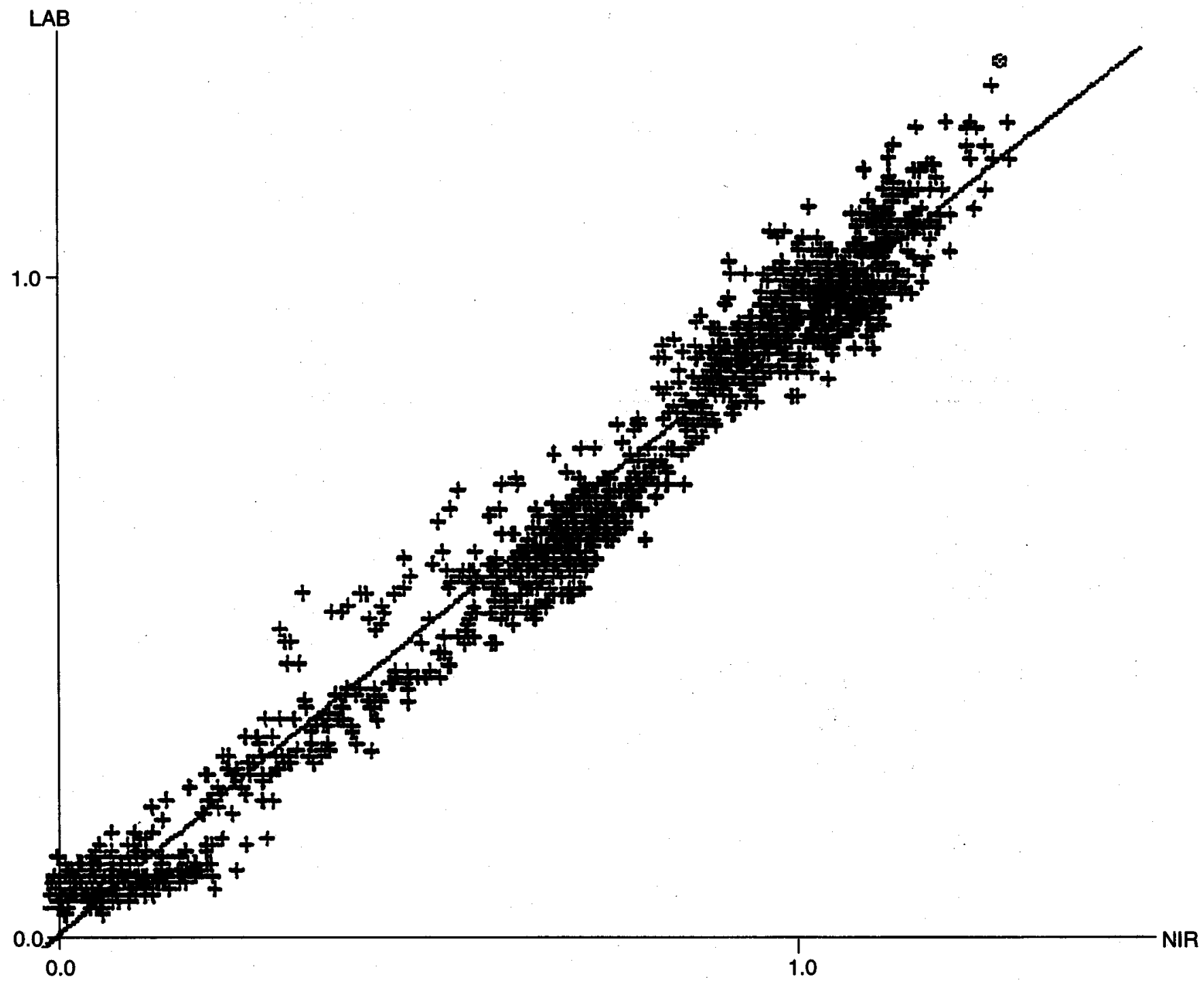

Figure 5.

Calibration curve of nicotine (full range). (Numer of samples: 1196; analytical range: 0.08-1.49 (1,41); F-test: 7764; corr.: 0.985; SEE: 0.064) 


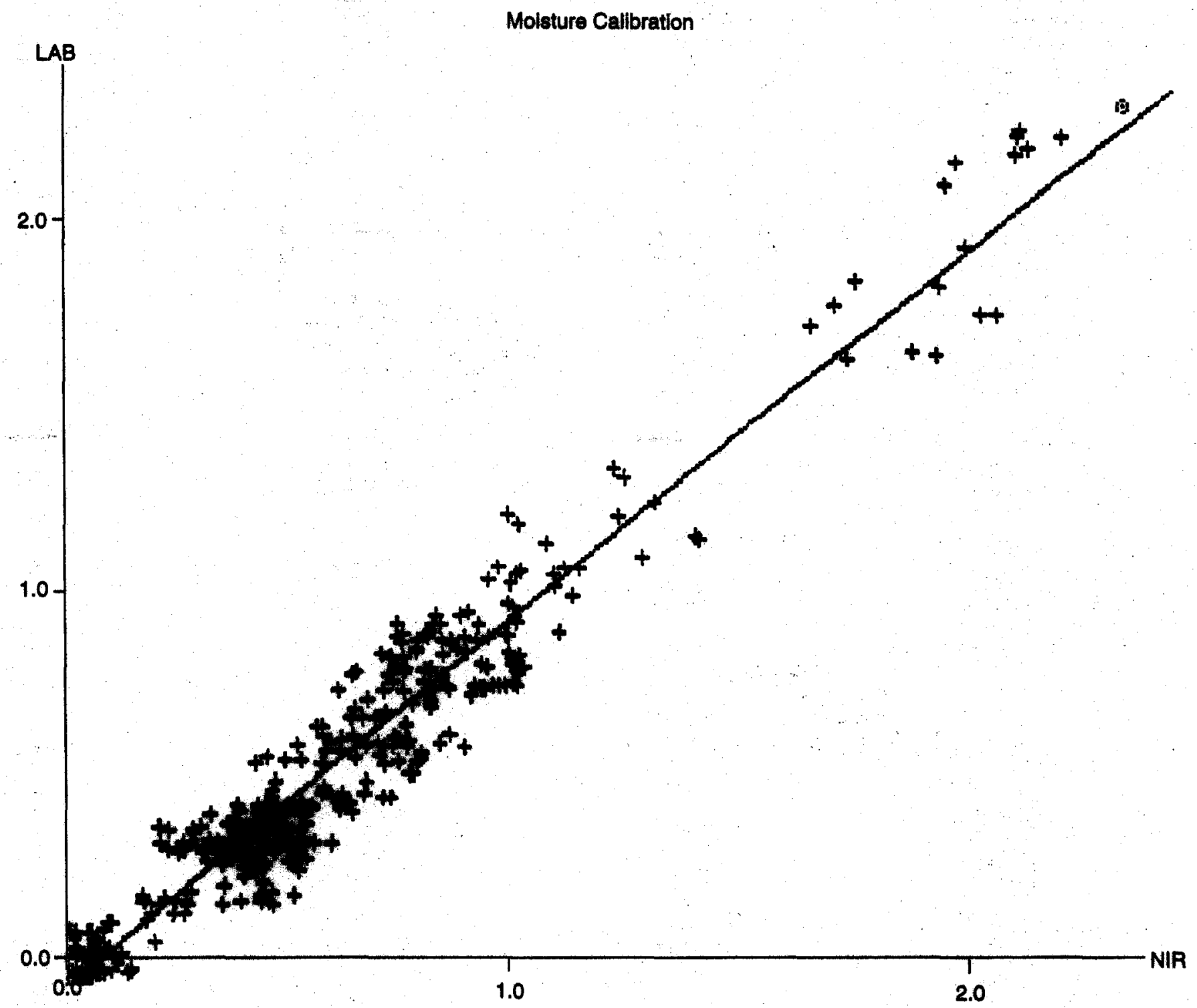

Figure 6.

Callbration curve of moleture. (Number of samples: 387; analytical range: 0.02-2.46 \% (2.44); F-test: 3192; corr.: 0.971; SEE: 0.109) 


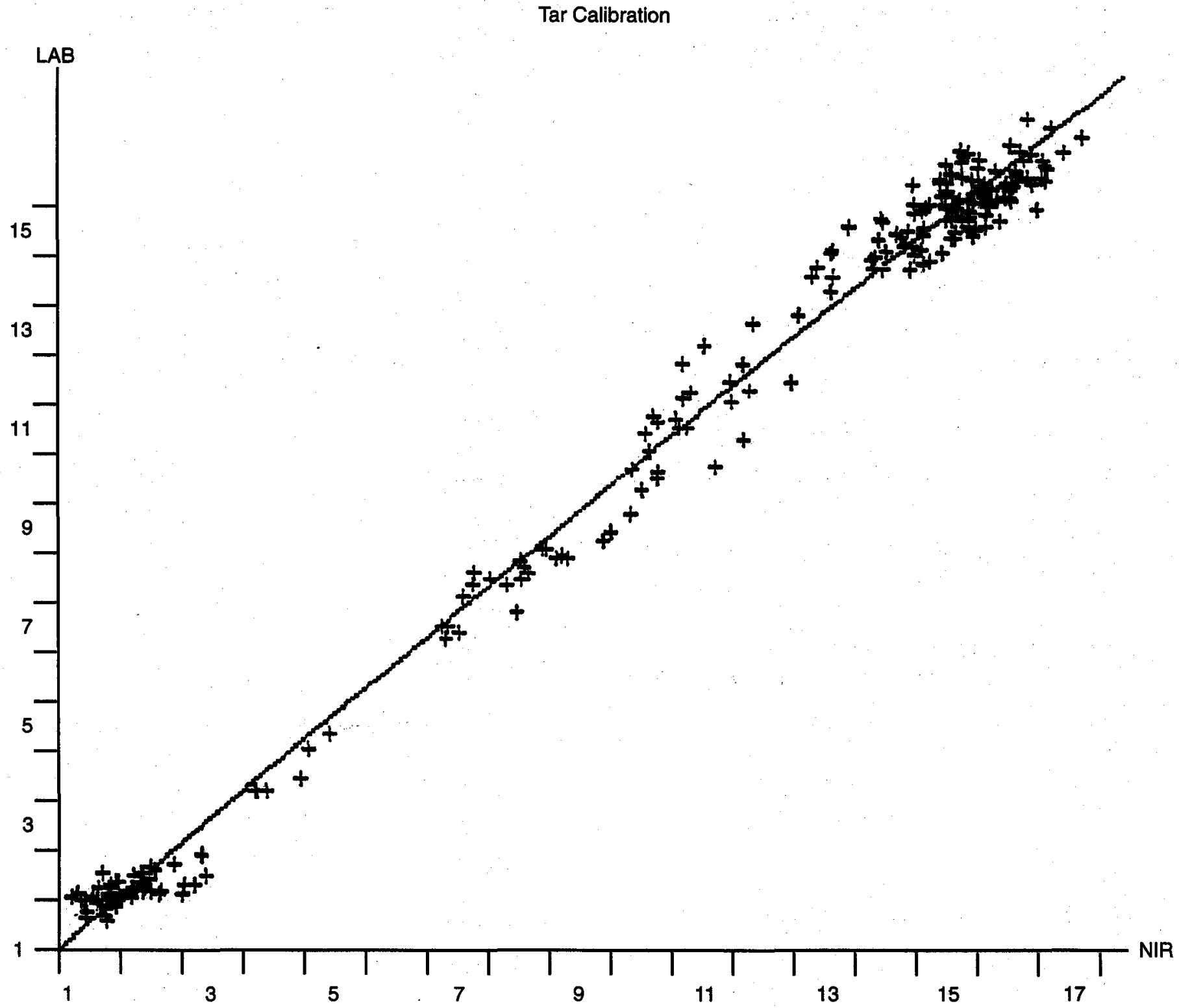

Figure 7.

Callbration curve of NFDPM (full range). (Number of samples: 230; analytical range: 1.13-17.15\% (16.02); F-test: 6436; corr.: 0.996; SEE: 0.539) 
3) multiple correlation coefficient;

4) standard error estimate;

5) standard error of prediction.

In the equations we determined, the following wavelengths (in $\mathrm{nm}$ ) were used:

for nicotine: $2310,2230,1818,1759,1722$;

for water: $\quad 2270,1940,1445$;

for NFDPM: 2345, 2336, 1940, 1818, 1734.

The results suggest, confirming the mathematical approach, that for each type of analysis, there is an optimal number of optical filters to use. This means that a multiple linear regression model using insufficient filters or too many filters, could show good statistical parameters, but will not have good stability and reliability. In other words, such an unbalanced calibration curve could give good results only when analyzing samples very similar to those used to construct the calibration.

Another fundamental point studied, because of the large number and different type of samples that were exam- ined, was how the spectroscopic information was utilized by the software. Practically, we have found that a single calibration is sufficient to determine water present in its most common value range, and a single calibration is sufficient to determine WTPM.

For nicotine, the situation is more complex: the calibration made over the entire range $(0.0-1.5 \mathrm{mg} / \mathrm{cig})$ showed good statistical parameters (correlation coefficient, F-test, T-test, SEE), but did not work well enough with menthol cigarettes and the SEP (standard error of prediction) was too high with low nicotine cigarettes.

To overcome this problem we divided the data set into three parts: the first one collecting nicotine data ranging between 0.0 and $0.25 \mathrm{mg} /$ cigarette, the second one collecting data $>0.25 \mathrm{mg} /$ cigarette and the last one measuring nicotine from menthol cigarettes. The results, shown below, indicate that correlation coefficients became somewhat worse, but the standard error of prediction became much better, especially in the low nicotine calibration.

Our actual calibrations have the following characteristics:

\begin{tabular}{|c|c|c|c|c|c|}
\hline & $\begin{array}{c}\text { Range } \\
\mathrm{mg} / \text { cigarette }\end{array}$ & $\begin{array}{c}\text { Correlation to } \\
\text { reference } \\
\text { method }\end{array}$ & $\begin{array}{c}\text { Standard } \\
\text { error estimate } \\
(\mathbf{m g}) \\
\end{array}$ & $\begin{array}{c}\text { Typical } \\
\text { repeatabllity } \\
(\mathbf{m g})\end{array}$ & $\begin{array}{c}\text { Typical } \\
\text { reproducibility } \\
\text { (mg) }\end{array}$ \\
\hline \multicolumn{6}{|l|}{ Nicotine } \\
\hline $\begin{array}{l}\text { Analysis integral program } \\
\text { (Figure 5) }\end{array}$ & $0.08-1.50$ & 0.985 & 0.064 & $\begin{array}{c}\text { (not } \\
\text { determined) }\end{array}$ & $\begin{array}{c}\text { (not } \\
\text { determined) }\end{array}$ \\
\hline $\begin{array}{l}\text { Analysis program } 1 \\
\text { suitable for analyzing } \\
\text { standard cigarette type }\end{array}$ & $0.22-1.50$ & 0.986 & 0.055 & 0.01 & 0.076 \\
\hline $\begin{array}{l}\text { Analysis program } 2 \\
\text { suitable for analyzing low } \\
\text { nicotine, tar cigarette type }\end{array}$ & $0.08-0.25$ & 0.851 & 0.020 & 0.03 & 0.080 \\
\hline $\begin{array}{l}\text { Analysis program } 3 \\
\text { suitable for menthol } \\
\text { cigarette type }\end{array}$ & $0.08-0.60$ & 0.991 & 0.020 & 0.02 & 0.080 \\
\hline \multicolumn{6}{|l|}{ Moisture } \\
\hline $\begin{array}{l}\text { Suitable for all cigarette } \\
\text { types and blank } \\
\text { Cambridge filters (Figure 6) }\end{array}$ & $0.02-2.50$ & 0.971 & 0.11 & 0.06 & 0.15 \\
\hline \multicolumn{6}{|l|}{ NFDPM (tar) } \\
\hline $\begin{array}{l}\text { Program } 1 \\
\text { Integral (Figure 7) }\end{array}$ & $\begin{array}{l}6.7-17.1 \\
1.1-17.1\end{array}$ & $\begin{array}{l}0.978 \\
0.996\end{array}$ & $\begin{array}{l}0.60 \\
0.54\end{array}$ & $\begin{array}{l}0.40 \\
0.40\end{array}$ & $\begin{array}{l}1.0 \\
1.0\end{array}$ \\
\hline
\end{tabular}


Repeatability is measured on the same instrument and reproducibility is measured on different instruments using the same calibration curve.

The transferability of calibrations from one instrument to another is the essential point in the NIRA applications. Different instruments have, generally, different optical paths and different optical constants (such as filter transparency, diffused light etc.), but only variations on the $\mathrm{CO}$ have been observed when the instrument is set with numeric constants obtained from a different instrument.

To confirm this important property, validation proofs were carried out with three different instruments of the same type and with an additional two instruments located in two different laboratories, in order to test the calibration validity with independent sets of samples.

The slope values were needed to compensate for the optical and construction characteristics among different instruments.

\section{CONCLUSION}

This paper discusses the potential application of a computerized near infrared spectrophotometer for measuring several mainstream smoke constituents collected on Cambridge filters.

This research has, in fact, initiated an overall analysis of NIRA in order to obtain more information on statistical and operative variables normally influencing the stability and reliability of the calibration curves.

Beyond the technical aspects of building calibrations, we found better results using a three steps calibration curve. This is generally correct but, on the other hand, the performance obtained by dividing the data set, should be evaluated by recognizing that a low range calibration will probably lose something in representativeness.

The general rule is that a calibration curve using a variety of data, represent a lot of information and can be used in many cases with varying levels, while a more specific calibration on a narrow sample type according to the type of calibrating sample can achieve more precise results.

\begin{tabular}{|c|c|c|c|c|c|}
\hline & $\begin{array}{c}\text { No. of } \\
\text { samples }\end{array}$ & Correlation & F-test & S.E.P. & Slope \\
\hline \multicolumn{6}{|l|}{ Nicotine } \\
\hline $\begin{array}{l}\text { LAB } 1 \\
\text { Inframatic } 1\end{array}$ & 419 & 0.967 & 5948 & 0.087 & 0.76 \\
\hline $\begin{array}{l}\text { LAB } 1 \\
\text { Inframatic } 2\end{array}$ & 61 & 0.973 & 917 & 0.076 & 0.86 \\
\hline $\begin{array}{l}\text { LAB 1 } \\
\text { Inframatic } 3\end{array}$ & 291 & 0.973 & 5144 & 0.076 & 1.01 \\
\hline LAB 2 & 58 & 0.846 & 131 & 0.098 & 0.96 \\
\hline LAB 3 & 80 & 0.934 & 500 & 0.076 & 0.84 \\
\hline \multicolumn{6}{|l|}{ NFDPM (tar) } \\
\hline LAB 1 & 178 & 0.991 & 9266 & 0.84 & 0.97 \\
\hline $\mathrm{LAB} 2$ & 14 & 0.977 & 256 & 0.34 & 0.86 \\
\hline LAB 3 & 58 & 0.910 & 256 & 1.50 & 1.10 \\
\hline \multicolumn{6}{|l|}{ Moisture } \\
\hline LAB 1 & 61 & 0.979 & 1312 & 0.12 & 1.00 \\
\hline LAB 2 & 60 & 0.980 & 1400 & 0.15 & 1.20 \\
\hline LAB 3 & 13 & 0.990 & 518 & 0.06 & 0.90 \\
\hline
\end{tabular}


Table 2.

Comparison between different methods In determination of NFDPM, water and nlcotine.

\begin{tabular}{|c|c|c|c|c|c|c|}
\hline Determination & Method & Speed & $\begin{array}{l}\text { Precision } \\
\text { and } \\
\text { Accuracy }\end{array}$ & $\begin{array}{l}\text { Simplicity } \\
\text { of the use. }\end{array}$ & $\begin{array}{l}\text { Pre-treat- } \\
\text {. ment }\end{array}$ & Instruments \\
\hline NFDPM & $\begin{array}{l}\text { Gravimetric } \\
\text { NIR }\end{array}$ & $\begin{array}{l}\text { very high } \\
\text { very high }\end{array}$ & $\begin{array}{l}\text { very high } \\
\text { medium }\end{array}$ & $\begin{array}{l}\text { very good } \\
\text { very good }\end{array}$ & $\begin{array}{l}\text { no } \\
\text { no }\end{array}$ & $\begin{array}{l}\text { Anal. balance } \\
\text { NIR Analyzer }\end{array}$ \\
\hline Water & $\begin{array}{l}\text { Karl Fischer Titration } \\
\text { NIR }\end{array}$ & $\begin{array}{l}\text { low } \\
\text { very high }\end{array}$ & $\begin{array}{l}\text { high } \\
\text { medium }\end{array}$ & $\begin{array}{l}\text { poor } \\
\text { very good }\end{array}$ & $\begin{array}{l}\text { simple } \\
\text { no }\end{array}$ & $\begin{array}{l}\text { KF Titrimeter } \\
\text { NIR Analyzer }\end{array}$ \\
\hline Nicotine & $\begin{array}{l}\text { Distillation } \\
\text { Continuous flow } \\
\text { Gas chromatographic } \\
\text { NIR }\end{array}$ & $\begin{array}{l}\text { low } \\
\text { high } \\
\text { low }\end{array}$ & $\begin{array}{l}\text { high } \\
\text { high } \\
\text { very high } \\
\text { medium }\end{array}$ & $\begin{array}{l}\text { poor } \\
\text { poor } \\
\text { poor } \\
\text { very good }\end{array}$ & $\begin{array}{l}\text { no } \\
\text { simple } \\
\text { simple } \\
\text { no }\end{array}$ & $\begin{array}{l}\text { Distiller and } \\
\text { spectrophotometer } \\
\text { Auto Analyzer } \\
\text { Gas chromatograph } \\
\text { NIR Analyzer }\end{array}$ \\
\hline
\end{tabular}

The calibration procedure is the key to success. Statistics are needed to design the calibration, make the best choice of wavelengths, and estimate the accuracy of the calibration. This technique does not, however, replace chemical knowledge and common sense but complements them. The most important operator task is capacity to blend statistical techniques, chemical knowledge and common sense in the proper way.

NIRA is a rapid, non-destructive method which may reduce dramatically the number of tests to be carried out for an official method. In fact, utilizing the method as a screening device, it is possible to analyze more samples for product control and reduce the exposure of the analyst to potentially dangerous, toxic chemicals.

The comparison table (Table 2) shows the advantages of NIRA with respect to the most common analytical methods, that is speed and simplicity. However, the calibration curves have to be carefully made and periodically checked.

\section{REFERENCES}

1. Ben-Gera, I and K. H. Norris: Direct spectrophotometric determination of fat and moisture in meat products; J. Food Science 33 (1966) 64-67.

2. Hymowitz, T., J. W. Dudley, et al.: Estimations of protein and oil concentration in corn, soybean, and oat seed by near-infrared light reflectance; Crop Science 14 (1974) 713-715.
3. McClure, W. F.: Rapid spectrophotometric analysis of the chemical composition of tobacco. Part. 1: Total reducing sugars; Beitr. Tabakforsch. 9 (1977) 1318.

4. Osborne, B. G.: Principles and practise of near infrared (NIR) reflectance analysis; J. Fd. Technol. 16 (1981) 13-19.

5. Osborne, B. G.: Investigation of the performance of an improved calibration for the determination of protein in UK home-grown wheat by near infrared reflectance analysis; J. Sci. Food Agric. 34 (1983) 1441-1443.

6. Isaac, R. A. and W. C. Johnson: Near infrared reflectance spectroscopic determination of protein nitrogen in plant tissue; J. Assoc. Off. Anal. Chem. 67 (1984) 506-509.

7. Williams, P. C., K. H. Norris, et al.: Determination of amino acids in wheat and barley by near infrared reflectance spectroscopy; J. Food Science 49 (1984) 17-20.

8. Osborne, B. G. and T. Fearn. Near infrared spectroscopy in food analysis; Flour Milling and Baking Research Association, Chorleywood, John Wiley \& Sons, Inc., New York, N.Y., 1986.

9. Bolling, H.: Possibilities and limits at the application of NIR measurement technique in the field of the breeding, trading and processing of cereals; Near Infrared Spectroscopy Conference, University of East Anglia, Norwich, UK,, 12-17th July 1987. 
10. Stark, E.: The physics and chemistry of near-infrared spectroscopy; Near Infrared Spectroscopy Conference, University of East Anglia, Norwich, UK, 12-17th July 1987.

11. Weyer, L. G.: Industrial applications of NIR reflectance; Near Infrared Spectroscopy Conference, University of East Anglia, Norwich, UK, 12-17th July 1987.

12. Puchwein, G.: Selection of calibration samples for near infrared spectroscopy by factor analysis of spectra; Anal. Chem. 60 (1988) 569-573.

13. Norris, K. H.: History, present status, and future prospects for NIRS; in Analytical application of spectroscopy, edited by C. S. Creaser and M. C. Davis, Royal Society of Chemestry, Burlinghton House, London, 1988.

14. McClure, W. F. and W.W. Weeks: Rapid spectrophotometric analysis of the chemical composition of tobacco. Part 2: Total alkaloids; Beitr. Tabakforsch. 9 (1978) 267-274.

15. Long, T. M. and P. Sadler: Infrared reflectance to the tobacco industry; Presented by T. M. Long at the 8th Technicon International Congress, London, 12-14th December 1978.

16. McClure, W. F. and R.E. Williamson: Rapid spectrophotometric analysis of the chemical composition of tobacco. Part 3: Polyphenols; Beitr. Tabakforsch. Int. 11 (1982) 219-227.

17. Bense, T. and C. Gastellu: Estimation of total volatile bases in tobacco by near infrared (NIR) reflectance spectrophotometry; Tobacco Science 27 (1983) 92-94.

18. McClure, W. F: Status of near infrared technology in the tobacco industry; International Symposium on Near Infrared Spectroscopy, Melbourne, Australia, 15-16th Oct. 1984.

19. McClure, W. F. and R.E. Williamson: Rapid spectrophotometric analysis of the chemical composition of tobacco. Part 4: Total nitrogen; Tobacco Science 30 (1986) 109-111.
20. Heckman, R. A., et al.: Transfer of near-infrared monochromator calibrations for the tobacco constituents to tilting-filter instruments; Anal. Chim. Acta 192 (1987) 197-203.

21. Delac, $S$., et al.: Determination of total alkaloids and total nitrogen by near infrared reflectance spectroscopy; International Coresta Symposium, Kallithea, Halkidiki, Greece, 7-11th Oct. 1990.

22. Koller, K. B., C.E. Thomas, et al.: Puff-by-puff determination of gas phase acetaldehyde, $\mathrm{HCN}, \mathrm{NO}$ and $\mathrm{CO}$ using FTIR spectrometry; International Coresta Symposium, Kallithea, Halkidiki, Greece, 7 11th Oct. 1990.

23. Lidzey, R.G. and G.P. Savage. An automated procedure for the determination of total alkaloids in cigarette smoke using on-line cyanogen chloride generation from low hazard starting materials; Beitr. Tabakforsch. Int. 13 (1986) 151-155.

24. Cardinale, E.: Cigarette "smoke" Cambridge filters; Presented to Philip Morris, Switzerland, 1980 and 1989.

25. Di Luzio, C. Relazione sull'impiego dell'apparecchio Inframatic 8620 PerCon per la misura del tenore di acqua e nicotina nel fumo delle sigarette; Amministrazione Autonoma dei Monopoli di Stato, Manifattura Tabacchi, Bologna, Italy, September 1989.

26. Shreve, W. K., Ayers, P.H. and C.R.E. Coggins: Feasibility of using a near-infrared device for the estimation of nicotine presented to animals in inhalation studies; Toxicol. Methods 1 (1991) 84-88.

Authors' address:

Edoardo Cardinale, Esetek Instruments $\mathrm{Srl}$, Via Campi di Annibale 3, I.00046 Grottaferrata, Roma. 